\title{
Primary Mediastinal Large B-Cell Lymphoma As an Incidental Finding: Report of a Case
}

\author{
Tesadüfen Tanı Konulan Primer Mediastinal Büyük B Hücreli Lenfoma Olgusu
}

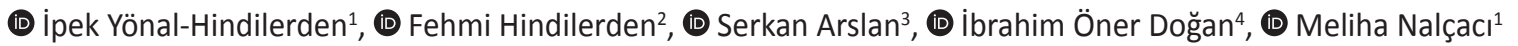 \\ 'Istanbul University Istanbul Faculty of Medicine, Department of Internal Medicine, Division of Hematology, Istanbul, Turkey \\ ${ }^{2}$ Dr. Sadi Konuk Training and Research Hospital, Clinic of Hematology, Istanbul, Turkey \\ ${ }^{3}$ Dr. Sadi Konuk Training and Research Hospital, Clinic of Radiology, Istanbul, Turkey \\ ${ }^{4}$ istanbul University Istanbul Faculty of Medicine, Department of Pathology, Istanbul, Turkey
}

To the Editor,

A 21-year-old female was examined for an incidentally detected left parahilar mass on chest radiograph which was taken at the time of job application (Figure 1a). Thoracic computed tomography revealed a mass of $10 \times 9 \times 5 \mathrm{~cm}$ with irregular lobulated borders in the anterior mediastinum invading the pericardium (Figure 1b). Histopathological examination of the anterior mediastinotomy material revealed large neoplastic $B$ cells staining positive for CD20 and MUM-1, negative for CD10, and with a high Ki-67 proliferation index (80\%-90\%) (Figure 2). On positron-emission tomography scan, only the mediastinal mass showed increased fludeoxyglucose uptake (SUV $_{\max }$ : 18) (Figure 1c). Final diagnosis was stage 1A primary mediastinal large B-cell lymphoma (PMBCL). After 6 cycles of R-CHOP, PET scan showed partial anatomical and metabolic response. R-CHOP was completed to 8 cycles followed by mediastinal radiation. She has now been disease-free for 2 years.

PMBCL, accounting for 2\%-4\% of all non-Hodgkin lymphomas, often presents as a bulky anterior mediastinal mass and often

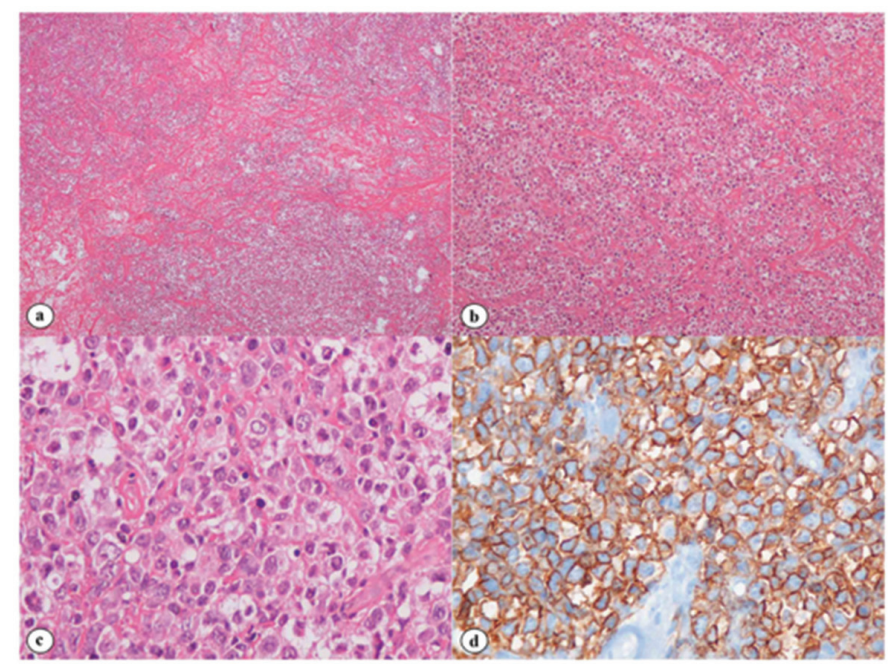

Figure 2. Histopathological examination of the mass. a) Diffuse neoplastic infiltration on a partially sclerotic background (hematoxylin and eosin stain, 40 ). b) The clear-cell appearance of the tumor cells (hematoxylin and eosin stain, 100). c) The appearance of round nuclei (centroblast-like) and clear cytoplasm (hematoxylin and eosin stain, 400). d) Infiltrated cells with CD20 expression (hematoxylin and eosin stain, 400).
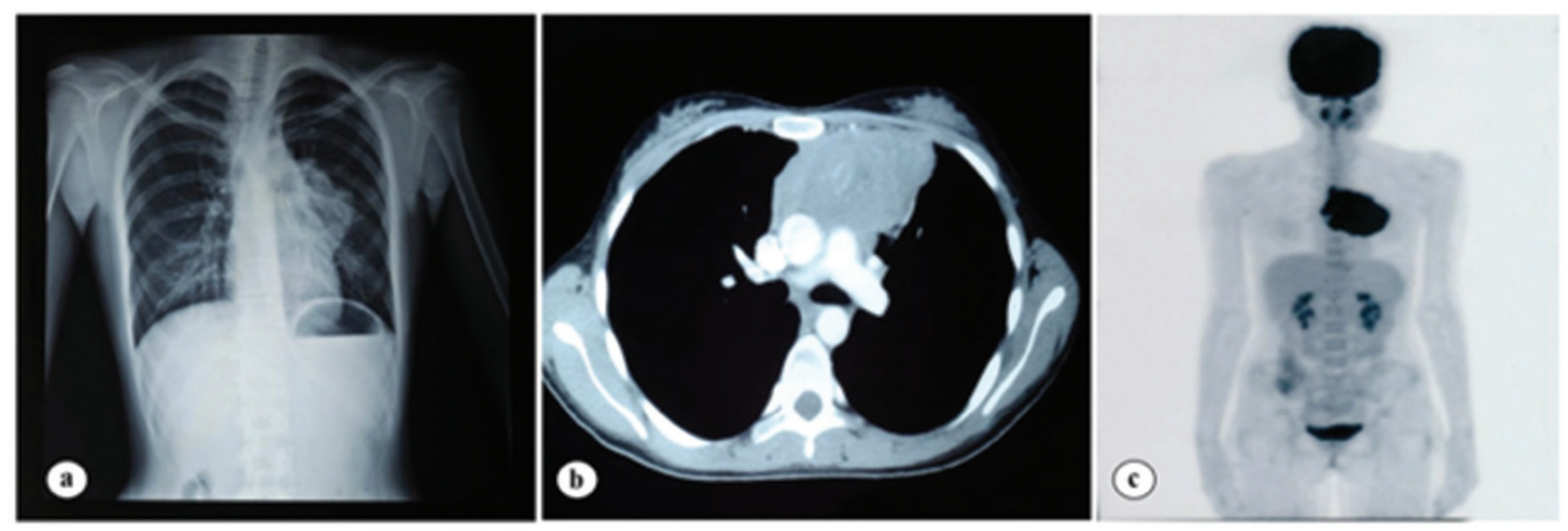

Figure 1. Radiological findings of primary mediastinal B-cell lymphoma. a) Appearance of the left parahilar mass on chest plain film. b) Thorax computed tomography depicts a mass of 10x9x5 cm in the anterior mediastinum with irregular lobulated borders invading the pericardium. c) Positron-emission tomography scan shows increased fludeoxyglucose uptake in the tumor. 
invades surrounding structures such as the heart, lungs, pleura, and superior vena cava $[1,2]$. Patients often present with cough, dyspnea, chest pain, and superior vena cava syndrome [3]. $\mathrm{R}-\mathrm{CHOP}$ plus consolidative mediastinal radiation is often an option [4]. Herein, we report a rare case of asymptomatic PMBCL with bulky mediastinal mass in which the patient achieved complete remission after R-CHOP and mediastinal radiation.

Keywords: Mediastinal neoplasm, B-cell lymphoma, PMBCL

Anahtar Sözcükler: Mediastinal kitle, B hücreli lenfoma, PMBCL

Conflict of Interest: The authors of this paper have no conflicts of interest, including specific financial interests, relationships, and/or affiliations relevant to the subject matter or materials included.

\section{References}

1. Savage KJ. Primary mediastinal large B-cell lymphoma. Oncologist 2006;11:488-495.

2. Bhatt VR, Mourya R, Shrestha R, Armitage J0. Primary mediastinal large B-cell lymphoma. Cancer Treat Rev 2015;41:476-485.

3. Abou-Elella AA, Weisenburger DD, Vose JM, Kollath JP, Lynch JC, Bast MA, Bierman PJ, Greiner TC, Chan WC, Armitage JO. Primary mediastinal large B-cell lymphoma: a clinicopathologic study of 43 patients from the Nebraska Lymphoma Study Group. J Clin Oncol 1999;17:784-790.

4. Giri S, Bhatt VR, Pathak R, Bociek RG, Vose JM, Armitage JO. Role of radiation therapy in primary mediastinal large B-cell lymphoma in rituximab era: a US population-based analysis. Am J Hematol 2015;90:1052-1054.

${ }^{\circ}$ Copyright 2018 by Turkish Society of Hematology

Turkish Journal of Hematology, Published by Galenos Publishing House

\title{
A Rare Late Complication of Port Catheter Implantation: Embolization of the Catheter
}

Nadir Görülen Bir Port Kateter Geç Komplikasyonu: Kateter Embolizasyonu

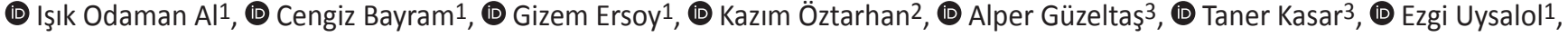 \\ (D) Başak Koç¹, (D) Ali Ayçiçek¹, (D) Nihal Özdemir1 \\ 1 University of Health Sciences, Istanbul Kanuni Sultan Süleyman Training and Research Hospital, Clinic of Pediatric Hematology and Oncology, \\ istanbul, Turkey \\ 2 University of Health Sciences, Istanbul Kanuni Sultan Süleyman Training and Research Hospital, Clinic of Pediatric Cardiology, Istanbul, Turkey \\ 3 University of Health Sciences, Istanbul Mehmet Akif Ersoy Thoracic and Cardiovascular Surgery Training and Research Hospital, Clinic Pediatric \\ Cardiology, İstanbul, Turkey
}

\section{To the Editor,}

Children with cancer need long-term venous access due to the long duration of therapy. Long-term totally implantable port devices (TIPDs) are widely used in these patients for administration of chemotherapeutic agents, parenteral nutrition, fluids, and blood products [1,2]. Fracture and embolism of TIPDs are rare complications but may cause serious results and mortality, including pulmonary artery embolism, sepsis, arrhythmias, and perforation of the caval vein $[3,4,5]$. Herein, we present a 9 -yearold male patient with pre-B acute lymphoblastic leukemia who was admitted to the outpatient pediatric hematology and oncology clinic at the $13^{\text {th }}$ month of maintenance therapy due to new onset of non-flushing catheter. The patient had no other complaints. On posterior anterior chest $\mathrm{X}$-ray, the catheter was found to be disconnected from its reservoir (Figure 1). Echocardiography

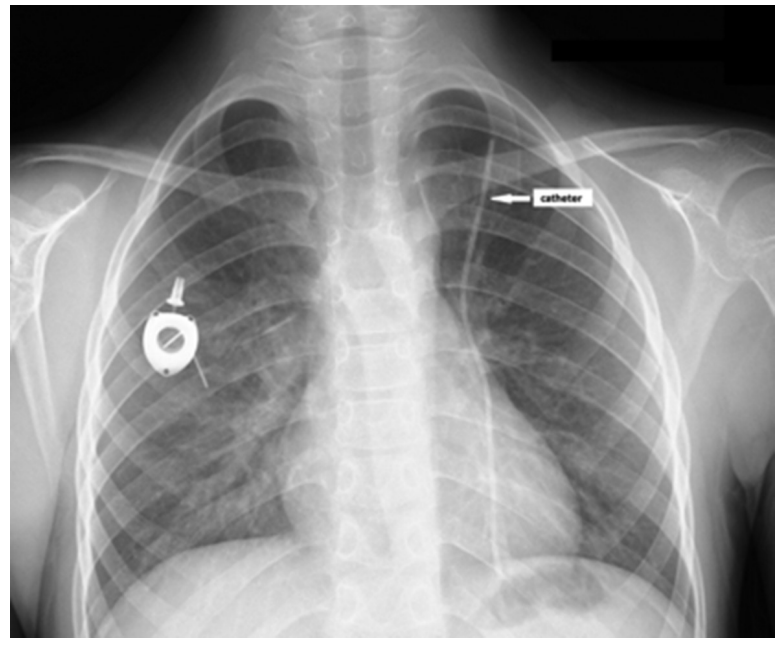

Figure 1. Chest $\mathrm{X}$-ray showing disconnection of the catheter from its reservoir. 